\title{
On the claim that noun complement clauses are relative clauses
}

\author{
Carlos de Cuba ${ }^{*}$
}

LSA Annual Meeting, Minneapolis, January 2-5, 2014

1. Introduction. A number of recent papers (Kayne 2008, 2010, Arsenijević 2009, Haegeman 2012, among others) have argued that so-called noun complement clauses (NCCs) as in (1) should be analyzed as relative clauses (RCs), as in (2).

(1) a. the fact that they're here

b. the claim that John kissed Mary

(2) a. the man that I saw

b. the claim that John made

Though the works cited above differ greatly in the details, they share the intuition that NCCs are RC variants. For example, Kayne (2008) posits that (1a) is derived from (3) with a silent in and its object fact relativized, as in (4).

(3) They're here, in fact.

(4) The fact ${ }_{i}$ that they're here in $t_{i}$.

Similarly, for Arsenijević (2009) the contents of ForceP are relativized and for Haegeman (2012) relativization involves operator movement from a TP position. The main goal of this paper is to present evidence against a general analysis of NCCs as RCs. In section 2, I present the main empirical evidence provided in favor of the RC analysis. In sections 3, 4 and 5, I provide crosslinguistic data that show NCCs displaying non-RC-like behavior, weakening the force of the evidence in section 2 and calling into question any strong claims that NCCs and RCs share the same type of structures across all languages. Section 6 concludes the discussion.

2. Empirical evidence presented for the RC view. The main empirical evidence presented in favor of the NCC as RC view is provided in (5) through (8), which show that in many languages, the same morphological item is used for both RCs and NCCs. In all of these cases, the relative marker used in the RC (a) examples is also used in the NCC (b) examples (and (8c)).

a. een gezin dat drie kinderen heft

(Brabant Dutch)

a family $\mathbf{C}$ three kids has

"a family that has three kids"

b. het problematische puntje dat hij drei kinderen heft

the problematic point $\mathbf{C}$ he three kids has

"the problematic point that he has three kids"

(Arsenijević 2009:46)

(6)

a. to što me $\quad$ plaši
that wh me.ACC frightens

(Serbo-Croatian)

"the thing that frightens me"

\footnotetext{
* Data thanks to Vesela Simeonova (Bulgarian), Maija Jalkanen-Sargent (Finnish) and Annika Wendt (Swedish). Thanks also to Clare Halpert for making me aware of the Durban Zulu facts below. Thanks also to the students in my fall 2013 syntax seminar at The University of Calgary and the audiences at ACOL 2012 at University of Lethbridge and LSA 2014 in Minneapolis for helpful questions, comments and discussion. Any errors here are of course my own. Author: Carlos de Cuba, University of Calgary (lin200cdc@ hotmail.com).
} 
b. to što me (on) plaši

that wh me.ACC he.NOM frightens

"(the fact) that he frightens me"

(Arsenijević 2009:46)

(7) a. John-I sakwa-lul kkak-un khal

John.NOM apple.ACC peel-Adnom. knife

(Korean)

"the knife with which John peeled an apple"

b. John-I sakwa-lul mek-un sasil

John.NOM apple.ACC eat-Adnom. fact

"the fact that John ate an apple"

(Arsenijević 2009:46, citing Cha 1999)

(8) a. Hou thou thaw té we '= thà hin.

that rancid go REL pork curry

"that pork curry which has turned rancid" (Haegeman 2012:273, citing Nichols 2003)

b. [[ thu chàn tha te ] hsou té ] 'othi

he rich REALIS EVAL REL.REALIS NOM.know

"the knowledge of the fact that he is rich" (Haegeman 2012:273, citing Nichols 2003)

c. [[ thu nei mə kàun hpù ] hsou té ] kauláhalá

he stay NEG good NEG EVAL REL.REALIS rumor

"the rumor that he is/was ill" (Haegeman 2012 \& Nichols 2003, citing Soe 1999:56)

Arsenijević (2009:46) argues that the fact that the same lexical item is used in both NCC and RC constructions in a number of languages and the fact that these can be different classes of lexical items (complementizer in (5), wh-word in (6), adnominal marker in (7)) points to a deep parallel in the syntactic structure and semantics of NCCs and RCCs. However, I show in section 3 that a number of languages to not share the same parallels between these structures.

3. Evidence against the RC view. In contrast to the data in section 2, a number of languages with morphologically distinct declarative complementizers $(\mathrm{C})$ and relative complementizers (RelC) choose the declarative complementizers for NCCs, as in (9-11).

(9) det factum att/*som Johan var här

the fact $\mathbf{C} / *$ RelC Johan was here

(Swedish)

"the fact that Johan was here"

(10) huhu, että/*joka Johannes oli täällä

(Finnish)

rumour C/RelC Johannes was here

"the rumor that Johannes was here"

(11) Jainkoa badela/*nko froga bat

God part-is-C/*RelC-Adnom. proof one

"proof that God exists"

(adapted from de Rijk 2008:462)

The same holds for Bulgarian, as shown in (12). Interestingly, Bulgarian is cited for optionally allowing the relative complementizer deto instead of the declarative complementizer che in some factive sentential complements, as in (13) (see Haegeman 2012, Krapova 2010).

(12) Faktat che/*deto Ivan beshe tuk

fact.DEF $\mathbf{C} / *$ RelC Ivan was here

(Bulgarian)

"the fact that Ivan was here" 
(13) Petar sazhaljava che/deto Ivan vidja Maria.

Petar regrets C/RelC Ivan saw.3.SG Maria

"Petar regrets that Ivan saw Maria."

(Bulgarian)

(Simeonova 2013:2)

In fact, Krapova (2010) analyzes these sentential complements with deto as hidden RC constructions. However, if the NCC in (12) were indeed a RC, we might expect it to choose deto, not che, especially if Krapova's analysis is correct and deto signals a RC in Bulgarian.

Finally, In Durban Zulu (DZ), a relative marker appears in relative clauses (14a) and a declarative complementizer appears in sentential complements $(14 b) .{ }^{1}$ In (14c) we see that in NCCs, the declarative complementizer appears, not the relative marker.
a. a- ngi- bon- e abantu abagqoka izigqoko ezibomvu (D. Zulu)
NEG 1SG- see NEG AUG.2people AUG.REL.2.wear AUG.8hat AUG.REL.8.red
"I don't see the people wearing red hats."
b. a- ngi- cabang- i [ ukuthi uSipho u- bon- e muntu/lutho]
NEG 1SG- think- NEG that AUG.1Sipho 1S- see- PFV 1person/13thing
"I don't think Sipho saw anyone/anything.
(Halpert 2012:90)
c. [indaba y-okuthi w- a- thatha umhlala phansi] $\{\mathbf{y}-/ \mathbf{k w}-\}$ a- ngi- mangaza AUG.9news 9-that 1- PST- take AUG.1sit down \{9S-/17s-\} PST-1sg.o surprise
"The news that he retired surprised me."
(Halpert 2012:246)

Note also in (14c) that DZ NCCs show optional subject agreement in the matrix clause (class 9 $y$-agrees, class $17 \mathrm{kw}$-doesn't). If these NCCs were RCs, we might expect the agreement pattern to be the same. However, the agreement is mandatory in DZ RCs, not optional, as shown in (15).

(15) [indaba e- wu- yi- bhal- e phansi izolo ekuseni (D. Zulu) AUG.9news REL- 2ndSG- 9O- write- PST down AUG.5yesterday LOC.15morning esikoleni $] \quad\{\mathbf{y}-/ * \mathbf{k w}-\}$ a- ngi- mangaza LOC.7school \{9S-/*17S-\} PST- 1sg.O- surprise

"The news that you wrote down yesterday morning at school surprised me."

(Halpert 2012:248)

Once again, we find that the behavior of NCCs does not pattern with RCs, this time neither in complementizer choice nor subject agreement patterns.

In sum, in addition to the empirical evidence in favor of the NCC as RC analysis presented in section 2, there seems to be just as much cross-linguistic data regarding complementizer choice (and subject agreement) that points in the opposite direction.

4. Operators and the Swedish relative complementizer som. In addition to appearing in RCs, the Swedish RelC som appears in clefts (16a) and embedded questions (16b).

(16) a. Det var min idé som/*att vann priset. It was my idea $\mathbf{R e l C} / * \mathbf{C}$ won prize-the "It was my idea that won the prize."

b. Johan undrade vem som/*att hade öppnat dörren, Johan wondered who $\mathbf{R e l C} / * \mathbf{C}$ had opened door-the "Johan wondered who had opened the door."

\footnotetext{
${ }^{1}$ Note that the difference in the form of the complementizer (ukuthi vs. okuthi) has to do with the presence or absence of yo- (which Halpert (2012) analyzes as an associative marker) on the complementizer.
} 
Depending on one's analysis of RCs, clefts and embedded questions, it is plausible to conclude that the RelC som appears when some sort of operator resides or moves into the specifier of CP. The clefted phrase min idé in (16a) and the wh-phrase vem in (16b) both appear to the left of som. On the other hand, the $\mathrm{C}$ att appears in declarative sentences where no element appears in the specifier of CP. Even if this characterization of the Swedish som facts is off the mark, the fact that NCCs pattern with the declarative complements in complementizer choice and not with RCs casts doubt on the claim that NCCs and RCs have the same structure, at least in some languages.

5. More counterevidence: complementizer-drop. In English RCs, the complementizer is obligatory in subject relative clauses (17a), but optional in non-subject relative clauses (17b-c).

(17) a. I saw the man *(that) _ ate the pizza.

b. I saw the pizza (that) the man ate

c. I like the way (that) they solved the problem

As illustrated in (3) and (4) above, for Kayne (2008) fact is a relativized complement to a silent in. Wherever in fact originates, it is clear that it is not subject position since the subject is occupied by they in (3) and (4). For Arsenijević (2009) Force contents relativize and for Haegeman (2012) operator movement is from a TP position. Since these are not subject relatives either, under all of their analyses we might expect C-drop to be licit, counter to fact, as in (18). ${ }^{2}$

(18) a. The fact *(that) John is here infuriates Mary

b. I resent the fact *(that) Mary left

6. Conclusions. In this paper I have presented some cross-linguistic examples where NCCs do not behave like RCs in regards to complementizer choice, subject agreement and the availability of complementizer-drop. While these data in no way rule out the possibility that some languages might employ a RC strategy for NCCs, they do present a significant challenge for any analysis that claims that the RC strategy is universal for NCCs.

\section{References}

Arsenijević, Boban. 2009. Clausal complementation as relativization. Lingua 119:39-50.

Cha, Jong-Yul. 1998. Relative clause or noun complement clause: some diagnoses. In Park, B.S., Yoon, J.H.-S. (eds.), Selected Papers from the 11th International Conference on Korean Linguistics, University of Hawaii, 6-9 July 1998. International Circle of Korean Linguistics, Seoul. 73-82.

De Rijk, Rudolf P. G. 2008. Standard Basque: A Progressive Grammar. Cambridge, Mass.: MIT Press.

Haegeman, Liliane. 2012. Adverbial Clauses, Main Clause Phenomena, and the Composition of the Left Periphery: The Cartography of Syntactic Structures, Volume 8. Oxford: Oxford University Press.

Halpert, Claire. Argument licensing and agreement in Zulu. Ph.D. Dissertation, MIT.

Kayne, Richard. 2010. Why isn't this a complementizer? In Richard Kayne, Comparisons and Contrasts. Oxford University Press. 190-227. Also to appear in Peter Svenonius (ed.). Functional Structure from Top to Toe: A Festschrift for Tarald Taraldsen, Oxford University Press, New York.

Kayne, Richard. 2008. Antisymmetry and the lexicon. Linguistic Variation Yearbook 8: 1-31.

Krapova, Iliyana. 2010. Bulgarian relative and factive clauses with an invariant complementizer. Lingua, 120(5), $1240-1272$.

Nichols, Lynn. 2003. Attitude evaluation in complex NPs. Formal Approaches to Function in Grammar, 155-164. Simeonova, Vesela. 2013. Two Bulgarian declarative complementizers: che and deto. Undergraduate Honours Thesis. University of Calgary.

Soe, Myint. 1999. A Grammar of Burmese. Ph.D. Dissertation, University of Oregon.

\footnotetext{
${ }^{2}$ Note that Arsenijević 2009 does provide an analysis of the that-deletion facts. Due to space constraints, I leave discussion of this to future work.
} 